\title{
Grundtvigs prædiken 2. s.e. trin. 1840
}

\author{
Af Jette Holm
}

2. søndag efter trinitatis, 1840 , d. 28. juni blev Kristian den ottende kronet til konge på Frederiksborg slot.

Grundtvig skrev i den anledning flere hyldestdigte (jfr. Poet. Skr. VI). - Grundtvig prædikede 2. s.e.trin. i Vartov og tager anledning af kroningen til at udrede forskellen mellem folkeånd og Helligånd. Kongen har til sin kroning udvalgt ordene fra 1. Samuelsbog: „Så tog Samuel oliehornet og salvede David midt imellem hans brødre, og Herrens Ånd kom heftig over ham fra den samme dag og fremdeles." Grundtvig ved, at et land ikke kan styres ved Helligånden, så den ånd, der kan komme over kongen, er ikke Helligånden, men den danske folkeånd. Prædikenen slutter højstemt om den danske folkeånd, barneengelen, barnlighedens engel. Om den lyder det: uden I omvende Eder og blive som børn, komme I ingenlunde ind i Himmeriges rige, thi dette Rige hører børnene til. »Dermed gav Herren Barne-Engelen, den Danske Folkeaand, det herlige Vidnesbyrd, at skiøndt hverken han eller nogen Engel kan oplade Himmerigs Dør eller føre os derind, som kun er den Helligaands Gierning, saa er det dog Barne-Engelen, der ene kan og altid vil ledsage os til Dørren og lægge os paa Herrens Arme med Bøn om Hans Velsignelse, Hans evige Velsignelse i det himmelske Bad.«

I denne prædiken taler Grundtvig meget tydeligt om forholdet mellem folkeånd og Helligånd. Prædikenen slutter med at citere to vers om »Danmarks Engel « fra det samtidige digt: Kongeskifte og Folkehaab. (Poet. Skr. VI, s. 363ff.).

Prædikenen bringes her som et eksempel på en af de mange, store prædikener fra 1840erne, som stadig ikke er udgivet. (Bortset fra udvalget i Vartovprædikener).

Jeg har gennemlæst nogle årgange og er blevet overbevist om, at udgivelsen af Grundtvigs prædikener b $\varnothing r$ fortsættes. Der er store, højstemte prædikener, der kan udskrives som prosadigte; prædikener, hvor salmevers bliver til. Prædikenerne for eksempel i 1844 belyser Grundtvigs krise inden afskedsgudstjenesten og salmen: Sov sødt barnlille. Julen 1845 er højstemt, for nu bryder den gamle salmesang for første gang ud i Vartov med alt, hvad det betyder i Grundtvigs liv! 
Årene omkring krigen og grundloven vil også være spændende at følge, og ... hvem kan vide, hvad der skjuler sig i denne uåbnede skat!

En arbejdsgruppe bestående af prof. Chr. Thodberg, sognepræst Leif Kallesen, sognepræst Lars Toftdahl, cand theol. Elisabeth Albinus Glenthøj, D. Phil. Johannes B. Glenthøj og sognepræst Jette Holm er netop startet på opgaven med renskrivning af Grundtvigs prædikener fra 1840erne med henblik på udgivelse. Der er tale om en fortsættelse af Grundtvigs Prædikener 1821-26; 1832-39, der udkom på Gads forlag $1983 \mathrm{ff}$ under Chr. Thodbergs redaktion.

\section{Grundtvig 2. s.e. trin. 1840}

Jorden har sine store Feil og Brøst, og det er kun timeligt, men det var dog lige unaturligt, om vi foragtede det, og indbildte vi os, at det var Veien til at naae det høiere, det sande og evige Liv i Christo Jesu, da tog vi mærkelig feil, thi hvem der foragter Guds mindste Gave, faaer aldrig den Største, og desuden vil vort Folkeliv, det er den levende Følelse og Tankegang, der som et Folk er os eiendommelig, ligesaavel som det Liv Enhver af os modtog af Gud, da vi fødtes til Verden altid, naar det modtages og bruges med Taknemmelighed, forberede os til Christenfolkets evige Liv. - Ja, m.V. det danske Folks naturlige Lyst er Fred, Dets naturlige Liv er Billighed, Dets naturlige Drift er Mildhed, Dets naturlige Maal er varig Glæde, og jo mere vi derfor blive os det Danske Folkeliv bevidst, des klarere vil vi indsee, at denne Verden kan ikke give os hvad vort Hjerte begiærer, des dybere vil vi komme til at føle, at kun i Christi Rige findes det i Sandhed, hvad vi naturlig spørge om og hige efter -

Derfor $\mathrm{m}$. V. er det langtfra at Christendommen skulde formindske vor Deeltagelse i Alt hvad der er vigtigt for det Danske Folkeliv, og hvad er vel vigtigere for det, end den Aand, der besjæler Majestæten paa Danmarks Throne, den Aand, der besjæler vor uindskrænkede Konge, der umuelig kan have Magt og Myndighed til at giøre meget Godt uden ogsaa at have den til at giøre meget Ondt, til at hemme som til at fremme, til at forbittre som til at forsøde Folkelivet. Jo dybere Ærbødighed vi har for Christendommen, og jo fortroligere vi er med Dens Liv og Aand, der glædeligere vil det være os mellem 
Sprogene af den Hellige Skrift som vor Konge udvalgde sig til sin Kroning og Salving ogsaa at høre det af første Samuels Bog: saa tog Samuel Olie-Hornet og salvede David midt imellem hans Brødre, og Herrens Aand kom heftig over ham fra den samme Dag og fremdeles, thi vel kan vi, som oplyste Christne, hverken mene at den HelligAand med det christelige Liv skiænkes uden ved Troen og Daaben, heller ikke tillægge og tilskrive vore kirkelige Lærere og Tilsynsmænd den Fuldmagt, Gud kun gav sit Folks Ypperste-Præster og Propheter i det Gamle Testamente; men da vor Konge betragter Folket som sine Brødre, da er Folkets Aand allerede over ham, og naar han da $\emptyset$ nsker at en Aand fra Herren maa komme vældig over ham med Viisdom fra det Høie til at føre Septeret og Sværdet, saa Kronen straaler, Thronen styrkes, Ondskab bæver, Godhed jubler, Riget blomstrer, og den sande Gud æres, Hans Navn forherliges iblandt os, naar Kongen ønsker det, da skal vi sige Amen og være visse paa, at Folkets Aand, som skaber nærer og opholder Folkelivet, vil komme hæftig komme vældig over Kongen fra denne Dag og fremdeles. Ja m. V. jo mere Christne vi er, des vissere vil vi føle os derpaa, at enhver Konge som beder Herren om Aand, faaer sit Folks gode Aand, som er den af Herrens Aander, der netop paa det Sted kan oplyse Kongen, styrke Thronen, og befæste den Kiærlighed og Enighed mellem Kongen og alle hans gode og troe Undersaatter, der er ligesaa nødvendig til Kongens Lykke, som til Landets Flor.

Ja m. V. det er Aanden, som giør levende, siger Han, som veed hvad han siger og vidner hvad han haver seet, og det giælder om Menneske-Livet fra Først til Sidst og fra dets laveste til dets høieste Art og Grad. Det er Aandedrættet som giør Enhver af os legemlig levende, og det er et Aandepust fra den Høieste som alle Dage kan giøre Mennesker til levende Sjæle, saa der gives ligesaalidt noget Folkeliv paa Jorden uden tilsvarende Aand, usynlig men virkelig Livskraft, som der gives et christeligt Liv uden den Helligaand, og saamange Folkefærd med menneskeligt Hjerte og naturlig Sands for det Store og Ædle, Høie og Dybe, der udmærker Mennesket, skabt i Guds Billede og efter Hans Lignelse, saamange gode Guds Engle er ogsaa udsendte fra Thronen til at oplive, styrke og oplyse Folkene og deres Fyrster, saa de kan gaae deres afstukne Vei, og udrette deres beskikkede Gierning til Skaberens Ære, og denne Folkets Aand, som man kan spore i alle Dets gamle Bedrifter Sange, Love og Indretninger, giver sig tydelig tilkiende i deres Tungemaal, som paa det 
Nøieste svarer til deres særegne Hjertelag og Tankegang, thi Munden taler af Hjertets Overflødighed og kun naar Tungemaalets Aand er over os, tale vi med Liv og Varme, og tiltale Folkets Hjerte, hvorfor det ogsaa var Kiendemærket paa alle Aanders Aand, paa Gud den Helligaand, at Han, som Jesus Christus sendte, havde alle Tunger i sin Magt, saa Folk fra alle Verdens Hjørner forbavsede maatte udbryde er ikke alle disse Talere Galilæer, hvordan høre vi dem da udraabe Guds store og underlige Ting med vore Tunger. - Derfor er det Eet og det Samme enten vi sige, at vort Folkeliv er atter vaagnet, eller at Fædrenes Aand er igien kommet over vore Talere, saa de udtale store og dybe Ting med vore Tunger, har Modersmaalet $\mathrm{i}$ deres Magt til at udtrykke sig saa levende om det Usynlige, at vi ligesom see det for vore Øine, udtrykke sig saa folkelig baade om det Høie og det Dybe, at det tiltaler og bevæger os ikke som vi har Forstand og Kundskab, men som vi har Hjerte og naturlig Livlighed til, og det er aldeles umueligt, at et Folk ikke skulde glæde sig ved saaledes at besøges og tiltales af sin og sit Modersmaals Aand, og ligesaa umueligt, at et Folk kan leve op i denne Aand, uden at føle Modbydelighed for alt det Fremmede, der under Aandens Fraværelse og Folkedøden har trængt sig ind i Tungemaalet i Sæder, Love og Indretninger, og uden at føle stigende Lyst og Attraae efter at faae Alt igien dannet i Folkets Aand og læmpet efter Dets Hjerte, saa hvis vi nu skulde være saa ulykkelige at faae en Enevolds-Konge, der ikke var besjælet af Folkets Aand, ei elskede Dets Modersmaal, og ønskede, saavidt mueligt at læmpe sin Regiering, med Landets Love og Indretninger efter Folket, da kunde vel med Guds Hjelp, Folket taalmodig vente paa bedre Tider, men Kiærlighed og Enighed mellem en saadan Konge og Folket vilde være aldeles umuelige. - Nu derimod, da Himlens Gud, efter en gammel Konge, hvis Hjerte var som Folkets Hjerte, og i hvis Dage Fædrenes Aand gienfødte Modersmaalet og Folkelivet, og hvis høilivlige Ihukommelse derfor skal være udødelig hos os, og blomstre til Velsignelse fra Slægt til Slægt, da Himlens Gud efter Ham, gav os en yngre Fyrste af den samme Rod og Stamme, men i fuldmoden Manddoms-Alder, opfødt iblandt os, fortrolig med vort Modersmaal i al den Fylde, Dybhed og Deilighed, det endnu har aabenbaret, og da Han paa sin Kronings-Dag beder og opmuntrer os alle til at bede med sig, at Gud vil salve ham til en Konge i Danmark efter sit Hjerte, ligesom David var det i Israels Land og $\mathrm{i}$ sin Tid, ønsker og beder os ønske med sig at Herrens 
Aand maa komme fyrig over ham fra denne Dag og fremdeles; nu tør vi glæde os til den næste Fremtid, som en Nyaarstid for vort Modersmaal og for alt ægte Dansk, det er Alt hvad der er i Folkets gode Aand; thi visselig, hvis Kongen og Folket bede Herren om Hans Aand til at oplive og oplyse, styrke og opmuntre, styre og raade, forbinde og forene dem, da sender Han den af sine Aander, som Han veed, de kan have tilfælles, og det er nødvendig Folke-Aanden, thi der er intet Land under Solen, hvor hele Folket kan annamme den Helligaand saa de ei meer leve deres eget Liv men Hans, som er død og opstanden for os, og selv om vi var et saadant mageløst Folk, saa vi Alle med een Mund kunde bede Faderen i vor Herres Jesu Navn udgyde sin Helligaand over Kongen og Folket, selv da vilde Gud sende Engelen med, som er vor naturlige Aand, til at gaae for Herrens Ansigt og berede Hans Vei. - Ja m.V. det sømmer sig nu og det behøves at tale frit om de aandelige Ting, thi Natten er forgangen og Dagen kommet nær, blandt alle Jordens Folkefærd er Israel Guds Førstefødte, paa hvem Hans egen Aand naturlig hvilede, saa Israels store Seere havde Guds Syner og var Hans sande Propheter, ligesom Han var Israels Konge, som Han gav sine Love og sine Rette, og Han har, som skrevet staaer, ei gjort saaledes ved noget andet Folk paa Jorden, saa kun forgiæves har alle Folk i Christenheden meent, at de kunde tilegne sig alle Israels Fortrin og Forjættelser for dette Liv, at deres Konger kunde være som David, at Israels Love og Skikke kunde passe for dem, og at deres Lærere kunde maale sig med Israels Propheter og Apostler. Hvor det ikke var hovmodig Indbildning, var det dog Barne-Drømme, der aldrig gik eller kunde gaae i Opfyldelse, og Herren finder da ei heller blandt os en Forløber og Herold som Johannes den Døber, der af Moders Liv var fyldt med den HelligAand og gik frem i Elias Aand og Kraft at omvende Børnenes Hjerte til Forældrene og Forældrenes til Børnene og skaffe Herren et velberedt Folk. - Nei, hvert Hedning-Folk har sin Engel, som er deres Aand, som var fra Arildstid over deres store Mænd, Konger og Lovgivere, Sangere og Helte, og naar Folket, efter en aandløs Tid, da alt det Folkelige blev dødt og magtesløst, ydmyg sukker til Himlens Gud, at Han vil udsende sin Aand og skabe dem og fornye Jordens Skikkelse, og lade denne sin Aand komme fyrig over deres Konge, da sender Gud dem deres gode Engel og giør deres Konge som en saadan Guds Engel for deres Ansigt, og bruger ham til at berede Herrens Vei hos de Udvalgte af Folket, som vente paa Forløsning og 
have Hjerte til at troe paa Guds eenbaarne $\$ \varnothing n$ og at fatte det evige Liv, som er Guds Naadegave i ham, I Christo Jesu, vor Herre.

Dette er Guds Vei paa Jorden og Hans Saliggiørelses Orden blandt alle Hedninger, og sandelig, vi Danske have ei Aarsag til at knurre, men kun til at takke Herren og fryde os for Hans Ansigt, thi Snorerne ere faldne for os paa de liflige Steder, der er os en deilig Arv beredt, vor Engel er Ingen af de Glimrende, eller forbausende, og derfor siger Verden, vi har ingen Folke-Aand; men Gud har deri, som i alt, gjort denne Verdens Viisdom til Daarlighed, hvad allerede viser sig deraf, at der endnu er et Kongerige Danmark til, thi det var aabenbar blandt de Første paa Jorden, saa intet Hedninge-Folks Sagn gaae længer tilbage, og det maatte overleve mange Kongeriger, som glimrede paa Jorden, før det blev blandt de Sidste, og hvad forstaae de selvgjorte Viismænd sig paa Liv og Aand, som mene, at det Folk har ingen Aand, som, skiøndt det altid var lidet af Tal og beboede en Slette aaben til Lands og Vands, omringede af stridbare Folk, som nedsteg fra Bjergene, alligevel giennem et Par Aartusinder i det Mindste forsvarede sin Arv og Odel, blev tidlig det navnkundigste Folk i sin Kreds giemde troeligst sine Barndoms-Minder og har endnu et Tungemaal, kiendeligt fra alle Andres, ei mindre skikket og udviklet end noget andet levende Sprog, til at udtrykke Alt hvad der er høit og dybt, stort og deiligt mellem Himmel og Jord og i Menneskets Inderste, i Hjertets Lønkammer. - Hvad der har forblindet den selvkloge Verden, saa den vilde heller begribe Danmarks Lykke og stille Udvikling, som den største Urimelighed under Solen, end forklare dem af en herlig Aand, som i Løn oplyste og oplivede, ledte og styrede os, det er da Barnligheden hos vor Folke-Aand, større end hos nogen Anden, der virkede kiendelig i Hedninglande, saa naar vi følge vor Folkeaand, da har vi udvalgt den gode Deel, som ei skal tages fra os, thi det er i alle Maader Barne-Engelen, som Gud udsendte til vore Fædre, og vil lade fyrig komme over os, vore Konger og Lærere, naar vi har Lyst dertil og bede Ham derom. - Ja m. V. naar vi saaledes blive os det Danske Folkeliv bevidst, som et Aandepust af Barne-Engelen fra det Høie, da opgaaer der et mildt og deiligt Lys over hele det Folks Levnetsløb, vi naturlig tilhøre, da forstaae vi, hvorfor intet Folk har saa barnlig lagt deres Liv og Gods, Lykke og Skæbne i Enevolds-Kongens Haand, som det Danske, og hvorfor heller intet Folk har havt saa milde og faderlige Enevolds-Konger som vi, da see vi ogsaa hvilket herligt Varsel, det er for at Folkeaanden 
skal komme fyrig over Kongen fra denne Dag og fremdeles, at vor Dronning saa aabenbar er den Moderligste, som vel nogensinde bar Guld-Krone paa Jorden, saa det bevægede mig dybt og glædelig i Sjælen, da Majestæten engang i Vinter traadte ydmyg ind iblandt os, just som jeg læste for Alteret i Dagens Epistel »Den Fri, som er alles vores Moder, thi der staaer skrevet: vær glad, du Ufrugtsommelige, thi den Eenliges Børn er de fleste!«

Og skulde vi da endnu noget Øieblik kunne mene at vor FolkeAand, naar han kommer fyrig over Kongen og os, kunde føre os vild, eller hindre Nogen af os fra at komme til Christus eller blive hos Ham, hindre Nogen af os fra at annamme den Helligaand, eller fatte det evige Liv, Han alene kan skiænke, som Guds Naadegave i Christo Jesu vor Herre? Nei, det være langtfra, derover maatte det allerede berolige os, at vi see vor Dronning, hvem Barne-Engelen saa aabenbar tiltaler og ledsager, bøie Knæ med os i Jesu Navn og bekiende, at Jesus Christus er Herren til Gud-Faders Ære; men dog har vi et langt større Vidnesbyrd end dette i hans Ord, som siger: de smaa B $\varnothing$ rns Engle see altid min Himmelske Faders Ansigt, og atter, uden I omvende Eder og blive som Børn, komme I ingenlunde ind i Himmeriges Rige, thi dette Rige hører Børnene til. Dermed gav Herren Barne-Engelen, den Danske Folkeaand, det herlige Vidnesbyrd, at skiøndt hverken han eller nogen Engel kan oplade Himmerigs Dør eller føre os derind, som kun er den Helligaands Gierning, saa er det dog Barne-Engelen, der ene kan og altid vil ledsage os til Dørren og lægge os paa Herrens Arme med Bøn om Hans Velsignelse, Hans evige Velsignelse i det himmelske Bad. - Derfor m. V. lad os jo fastere Tro vi har paa Jesus Christus, jo fuldere Tillid vi har til Hans Guddoms-Ord, des inderligere og des gladere takke Herren, fordi Han sendte os sin Engel, gav vort Folk og Modersmaal en Aand ligesaa jævn og ligesaa yndig, som Marken vi beboe, og dog ligesaa omfattende, som Bølgen, der ombælter os, ligesaa let til at fare i Sky, som Lærken, der bygger i vor Agerreen, men synger Skaberens Lov i det Høie, hvor den tabes af Syne; ja, lad os stedse varmere elske den Aand, som kiendeligst lever og rører sig i vort jævne, men søde, dybe og deilige Modersmaal, visse paa, at naar vi blive ret fortrolige med den Guds Engel, da aabenbarer han os, at det var netop ham, der fik det glædeligste af alle Ærinder paa Jorden, det i himmelsk Glands at melde Hyrderne ved Bethlehem den store Glæde for Guds Folk under alle Himmelegne, at os er en Frelser født, den Herre Christus i 
Davids Stad, denne Jule-Engel, som derfor heller ingensteds er kiærligere mødt end hos vore Fædre, og skal med Guds Hjelp heller ingensteds see mere smilende Aasyn eller høre gladere Julesang end hos vore Børn fra Slægt til Slægt! Saa høre da Himmelens Gud Kongens og Dronningens og vore Bønner og lade denne sin Aand komme fyrig baade over Kongen og Folket fra denne Dag og fremdeles.

Danmarks Engel, som med Barnefinger

Løfted meer end nogen Kæmpe prud

Slaae kun frit med sine Svane-Vinger

Favne ømt vort Modersmaal, sin Brud!

Som et himmelfalden Dronning-Smykke,

Skinner over Skoven Danmarks Lykke!

Hil dig da, Kong Christjan med din Krone,

Med dit Folk og med dit Timeglar!

Danmarks Aand! sid herlig paa din Throne!

Modersmaal! giør Loven mild og klar

Folkesang! udbryd fra alle Munde,

Overstem alt Gny og Glam i Lunde!

Amen! i Jesu Navn Amen! 